\title{
TRANSPORT ACCESSIBILITY OF THE LAKE ECOSYSTEMS IN THE NORTH KAZAKHSTAN REGION AS A FACTOR OF TOURISM DEVELOPMENT
}

\author{
Pavel S. DMITRIYEV \\ North Kazakhstan Kozybayev University, Faculty of Geography and Ecology, \\ Petropavlovsk, Republic of Kazakhstan, e-mail: dmitriev_pavel@mail.ru \\ Ivan A. FOMIN \\ Tyumen State University, Institute of Geosciences, Faculty of Geoecology and Nature Management, Tyumen; Russian Federation and North \\ Kazakhstan Kozybayev University, Faculty of Geography and Ecology, Petropavlovsk, Republic of Kazakhstan, e-mail: iafomin@ mail.ru
}

\section{Tatyana V. NAZAROVA}

North Kazakhstan Kozybayev University, Faculty of Geography and Ecology, Petropavlovsk, Republic of Kazakhstan, e-mail: tvnazarova81@ mail.ru

\author{
Jan A. WENDT
}

University of Gdańsk, Faculty of Oceanography and Geography, Institute of Geography, Poland, e-mail: jan.wendt@ug.edu.pl

\begin{abstract}
Citation: Dmitriyev, P.S., Fomin, I.A., Nazarova, T.V., \& Wendt, J.A. (2021). TRANSPORT ACCESSIBILITY OF THE LAKE ECOSYSTEMS IN THE NORTH KAZAKHSTAN REGION AS A FACTOR OF TOURISM DEVELOPMENT. GeoJournal of Tourism and Geosites, 35(2), 289-296. https://doi.org/10.30892/gtg.35204-650
\end{abstract}

\begin{abstract}
The conducted research is aimed at assessing the current state of the tourist and recreational potential of the lake system in the region of North Kazakhstan (Kazakhstan). The research included the relationship between the distribution and natural diversity of reservoirs and landscapes and the density of the transport netw ork of the studied region in the administrative division of the region. The aim of the research undertaken is to indicate the spatial differentiation of the conditions for the development of tourism in relation to the degree of lake density and transport accessibility. The quantitative and qualitative characteristics of the lakes in terms of spatial diversity and transport accessibility in the region were presented. The anal ysis of the natural and recreational potential, with the use of statistical methods, satellite images, comparative analysis and field studies, made it possible to identify lake ecosystems that are already used or recommended for use as objects in tourism, as well as in the national economy. The analysis of the road network allows to conclude that its density, despite the higher indicators than the national average, does not fully allow the use of the region's tourist potential and may constitute a barrier to its development.
\end{abstract}

Key words: lakes, lake ecosystems, North Kazakhstan region, road network, tourism, transport

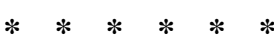

\section{INTRODUCTION}

Tourism in Central Asia, in the pre-Covid-19 era, was becoming more and more popular, which resulted in the interest of numerous researchers (Werner, 2003; Kantarci, 2007a; 2007b; 2007c; Smykova, 2015; Shakirova, 2015; Tleubayeva, 2018; Wendt, 2020). Due to its importance, numerous studies were conducted in Kazakhstan, but most of them concerned mountain regions located in the south and south-east of the country (Ziyadin and Takhtaeva, 2014; Aliyeva et al., 2019; Chernova and Sukhova, 2017; Chlachula, 2019; 2020; Kalugin et al., 2019). However, according to the government's decision, tourism is to constitute a rapidly growing sector of the economy, both at the national and regional level (Zhidkoblinova, 2013; Abubakirova et al., 2016; Tulbayeva et al., 2017), as well as with cross-border tourism, which plays an increasingly important role in the tourism services sector (Dunets et al., 2019; Więckowski and Saarinen, 2019; Cerić and Więckowski, 2020).

The North Kazakhstan region is characterized by unique physical and geographical conditions and historical heritage (Kuralbayev et al., 2016), which are important factors in the development of tourism. The region is located in the north of the Republic, on the southern edge of the West Siberian Lowland, partially occupying the Kazakh Highlands, known as Saryarka. The northernmost point is at $55^{\circ} 26^{\circ} \mathrm{N}$, in the south $52^{\circ} 13^{\prime} \mathrm{N}$, the westernmost point is $65^{\circ} 57^{\circ} \mathrm{E}$, and the easternmost point is $74^{\circ} 02^{`} \mathrm{E}$. The maximum distance from north to south is $375 \mathrm{~km}$, and from west to east $-602 \mathrm{~km}$. The region's boundaries and division were established on April 8, 1999, its area is 97.99 thousand $\mathrm{km}^{2}$. The region covers only $3.6 \%$ of Kazakhstan's territory, and $60 \%$ of its territory is arable land. The total length of the borders is $2,220 \mathrm{~km}$, including the Kustanay region $300 \mathrm{~km}$, Akmola - $810 \mathrm{~km}$, Pavlodar - $180 \mathrm{~km}$, he regions of the Russian Federation - 930 km, including Kurgan - 210 km, Tyumen $180 \mathrm{~km}$, Omsk $540 \mathrm{~km}$. The North Kazakhstan region is divided into 13 administrative counties (Table 1). In administrative terms, there are five cities in the region - Petropavlovsk, Bulaevo, Mamlyutka, Tayinsha, Sergeevka; four urban settlements - Smirnovo, Talshyk, Enbek (Novoishimskoye), Kishkenekol, 203 rural communes and 759 rural settlements.

\footnotetext{
* Corresponding author
} 
The administrative center of the region is Petropavlovsk, founded in 1752 as the fortress of St. Peter. Tourism is an important sector of the economy of each country (Zhakupov et al., 2015), and its importance is also appreciated in Kazakhstan (Zhidkoblinova, 2013; Ziyadin and Takhaeva, 2014; Syzdykbayeva et al., 2015), a country with a great potential of natural values, which include lake ecosystems of the North Kazakhstan region. Tourism, and especially sustainable tourism (Aimagambetov et al., 2018) and agritourism (Tleubayeva, 2018), balneotourism (Wendt, 2016), slow tourism (cittaslow) (Lewandowska et al., 2019) and a new techlogies as VR in tourism and economy (Ziyadin et al., 2014; Watkins et al., 2018; Korinth et al., 2019; Ziyadin et al., 2019a; 2019b; Bógdał-Brzezińska, 2020) play an important role as a perspective direction of development of its economy. However, its development still faces a number of barriers (Aliaskarov et al., 2017), among which transport, which is of key importance for the development of tourism (Bazarbekova et al., 2018), unfortunately holds a high position. The marketing of tourist services and their promotion are similarly poorly developed in Kazakhstan, also playing an important role in the development of this sector of the economy.

From the point of view of values conducive to the development of tourism, the natural resource potential of the research area is characterized by a high degree of lakes. Numerous lakes are used mainly for agricultural purposes (fishing) and as an important tourist asset (Nazarova et al., 2019; 2020). However, the use of lakes is limited, although the region ranks first in Kazakhstan in terms of their number. It is important that numerous studies emphasize the uniqueness of the origin of northern Kazakhstan's lakes at the geosystem and ecosystem level, which is important as a tourist asset. Scientific research on the study of lakes and river basins in northern Kazakhstan was published in the works (Beletskaya, 1987; Vodopyanova, 1985), confirming their high natural value and importance in the region's ecosystems. The study of landscape, recreational and tourism potential has been the subject of the work of numerous authors (Semochkina, 2012; Moldakova and Dmitriyev, 2016; Fomin et al., 2020; Wendt, 2020). Data on the number of lakes of the northern region of Kazakhstan (mainly in the old borders) vary from 2,500 to 3,500. This can be explained by taking into account the water reservoirs in the flood plains (periodic), which become lakes as a result of spring floods (Dmitriyev et al., 2016; Fomin, 2020).

The aim of the study is to analyze the spatial differentiation of tourism development conditions in relation to the degree of lakes and transport accessibility (Więckowski et al., 2014; Michniak et al., 2015). The analysis of the natural and recreational potential will allow the identification of lake ecosystems that are already used or recommended for use as objects in tourism and in the economy. The hypothesis verified in the research is the poor development of the road network, which is characterized by too low density. Which is a barrier to the development of mass tourism.

\section{MATERIALS AND METHODS}

The research material includes data collected on the basis of research carried out under the "Ekosfera" association, from the project "Natural resources and environmental management of Akimat in the North Kazakhstan region", from the research topic "Creation of a lake database in the North Kazakhstan Region" (Dmitriyev et al., 2013). Additional data comes from the interpretation of the collected satellite images of the region. All the factual material was verified and supplemented during field research. Mathematical and statistical methods, classic for research in the geography of tourism, were used to analyze the research results and the characteristics of lake ecosystems (Wendt and Bógdał-Brzezińska, 2018). Statistical methods were used for the classification of lakes and the analysis of spatial differentiation broken down into administrative units of the region. Administrative regions were subjected to a comparative analysis using quantitative methods (Creswell, 2003). Similarly, an analysis of the transport accessibility of lake ecosystems was carried out and their classification depending on the number, size of the area, lake level or ownership relations.

\section{RESULTS AND DISCUSSION}

As a result of the research, 2.328 lakes were identified in the northern region of Kazakhstan with a total area of 452430.5 ha. Lakes were defined as water reservoirs over 10 ha, excluding smaller reservoirs from the research.

Table 1. Lake rate index of administrative units of North Kazakhstan Region Source: https://elib.skolib.kz/catalog/item386.html and the authors' own calculations

\begin{tabular}{|l|c|c|c|c|}
\hline \multicolumn{1}{|c|}{$\begin{array}{c}\text { Name of } \\
\text { administrative units }\end{array}$} & $\begin{array}{c}\text { Area } \\
\text { (thous. km²) }\end{array}$ & $\begin{array}{c}\text { Number } \\
\text { of lakes }\end{array}$ & $\begin{array}{c}\text { Area of lakes } \\
\text { (hectares) }\end{array}$ & $\begin{array}{c}\text { Lake rate } \\
\text { index (\%) }\end{array}$ \\
\hline Region North Kazakhstan & 97.99 & 2328 & 452430.4 & 4.62 \\
\hline County Zhambyl & 7.46 & 826 & 62870.0 & 8.43 \\
\hline County Mamlyutsky & 4.10 & 404 & 28442.5 & 6.94 \\
\hline County Kyzylzhar & 6.15 & 244 & 21273.7 & 3.46 \\
\hline County Esil & 5.14 & 138 & 15468.8 & 3.01 \\
\hline County M. Zhumabayeva & 7.81 & 122 & 21015.5 & 2.69 \\
\hline County Akkayyn & 4.71 & 115 & 38608.1 & 8.20 \\
\hline County Ayyrtau & 9.62 & 95 & 31869.1 & 3.31 \\
\hline County Timiryazevsky & 4.51 & 91 & 21674.6 & 4.81 \\
\hline County Shal akyna & 4.84 & 82 & 17816.2 & 3.68 \\
\hline County Taiynshinsky & 11.42 & 68 & 29505.6 & 2.58 \\
\hline County Ualikhanov & 12.88 & 67 & 113015.2 & 8.77 \\
\hline County Akzhar & 8.04 & 39 & 32983.1 & 4.10 \\
\hline County G. Musrepov & 11.09 & 30 & 16038.0 & 1.45 \\
\hline City of Petropavl & 0.22 & 7 & 1850.0 & 8.41 \\
\hline
\end{tabular}

Table 2. Road network density in selected countries Source: (Bazarbekova et al., 2018 and https://www.cia.gov/the-worldfactbook/field/roadways/country-comparison/)

\begin{tabular}{|l|c|c|c|c|}
\hline \multicolumn{1}{|c|}{ Country } & $\begin{array}{c}\text { Area } \\
\left(\mathrm{km}^{2}\right)\end{array}$ & $\begin{array}{c}\text { Road } \\
(\mathrm{km})\end{array}$ & $\begin{array}{c}\text { Road density } \\
\left(\mathrm{km} / 100 \mathrm{~km}^{2}\right)\end{array}$ & $\begin{array}{c}\text { Year } \\
\text { of data }\end{array}$ \\
\hline Kyrgyzstan & 78867 & 34000 & 43.11 & 2018 \\
\hline Belarus & 207600 & 86600 & 41.71 & 2017 \\
\hline Ukraine & 603550 & 169694 & 28.12 & 2012 \\
\hline Tajikistan & 144100 & 30000 & 20.82 & 2018 \\
\hline Uzbekistan & 447400 & 86496 & 19.33 & 2000 \\
\hline Turkmenistan & 488100 & 58592 & 12.00 & 2002 \\
\hline Russia & 17098242 & 1283387 & 7.51 & 2012 \\
\hline Mongolia & 1564116 & 113200 & 7.24 & 2017 \\
\hline Afghanistan & 652230 & 34903 & 5.35 & 2017 \\
\hline Kazakhstan & 2724900 & 95409 & 3.50 & 2017 \\
\hline
\end{tabular}


Interesting results were obtained regarding the spatial distribution of lakes in the region of North Kazakhstan, which update and confirm the results of previous studies (Dmitriyev et al., 2016). The largest number of lakes is in the territory of the Zhambyl County. In second place is the Mamlyut region - 404 lakes. The third area of Kyzylzhar - 244 lakes. The smallest number of lakes is in the Akzhar County - 39, within G. Musrepov - 30 lakes and the city of Petropavel - 7 lakes. However, in the latter case, numerous smaller water tanks should be noted (Table 1).

The research allowed to determine the total area of lakes, which amounted to 452430.4 ha. Research shows that the lakes are very unevenly distributed in the territory of the North Kazakhstan region. Thus, the largest area of lakes, and hence the lake index, is in the Ualikhanovsky County - 113015.2 ha. The Zhambyl region is in second place -62870.0 ha. Smaller values of the total lake area are found in the Shal akyn regions - 17816.2 ha, G. Musrepov - 16038.0 ha, Esilsky 15468.8 ha. The area of lakes in the city of Petropavlovsk was 1850.0 ha, which gives it a high lake index. In order to achieve the aim of the research, apart from determining the lake density index, it was necessary to analyze the spatial differentiation of the road network density. It was carried out in terms of the entire road network and its division into national and regional roads. According to the literature (Page, 2004; Bazarbekova et al., 2018; Dinu, 2018), the transport network, the wider communication accessibility is crucial for the implementation of various forms of tourism. When researching the North Kazakhstan region, it should be borne in mind that both the size of the country and the region and the degree of development of the transport network should be analyzed in relation to the geographical conditions of Central Asia and the country's population density (18 million). And its comparison to the density of the road network of classic European tourist destinations (e.g. Austria, France, Germany and even to Belarus or Ukraine) is not substantively justified (Table 2).

The analysis of the transport network in terms of the length of roads and railways in the region allows it to be concluded that the main role is played by road transport. The available railway lines limit the traffic to the stations, among which a large railway junction stands out - the city of Petropavlovsk. The road network is differentiated into roads of national (republican) importance and regional roads. The total length of all national and regional roads is $3905 \mathrm{~km}$. National roads constitute $37.5 \%(1468 \mathrm{~km})$ and regional roads $62.5 \%(2437 \mathrm{~km})$. Despite the low density of the road network, especially national roads in some regions, in the case of Kazakhstan, it can be concluded that the road network of the North Kazakhstan region $\left(3.5 \mathrm{~km} / 100 \mathrm{~km}^{2}\right)$ is slightly, but still higher than the national average $\left(4.0 \mathrm{~km} / 100 \mathrm{~km}^{2}\right)$. This allows for a good degree of road development in the studied region compared to the whole country, but does not translate into sufficient transport accessibility to naturally valuable lake areas.

Table 3. Diversification of the road network and lakes rate index

in the administrative units of the North Kazakhstan region (Source: https://elib.skolib.kz/catalog/item386.html and the authors' own calculations)

\begin{tabular}{|c|c|c|c|c|c|c|}
\hline \multirow{3}{*}{ Region, county and city } & \multirow{3}{*}{$\begin{array}{c}\text { Area } \\
\text { (thous. } \\
\mathrm{km}^{2} \text { ) }\end{array}$} & \multicolumn{4}{|c|}{ Roads } & \multirow{3}{*}{$\begin{array}{c}\text { Lakes } \\
\text { rate index } \\
(\%)\end{array}$} \\
\hline & & \multicolumn{2}{|c|}{ Total } & \multicolumn{2}{|c|}{\begin{tabular}{l|l} 
tate & regic \\
\end{tabular}} & \\
\hline & & $\mathrm{km}$ & \multicolumn{3}{|c|}{$\mathrm{km} / 100 \mathrm{~km}^{2}$} & \\
\hline North Kazakhstan region & 97.99 & 3905.0 & 3.99 & 1.50 & 2.49 & 4.62 \\
\hline County G. Musrepov & 11.09 & 664.3 & 5.99 & 2.96 & 3.03 & 1.45 \\
\hline County Taiynshinsky & 11.42 & 613.2 & 5.37 & 1.24 & 4.13 & 2.58 \\
\hline County Akzhar & 8.04 & 374.2 & 4.65 & 1.01 & 3.65 & 4.10 \\
\hline County Shal akyna & 4.84 & 223.4 & 4.62 & 2.22 & 2.40 & 3.68 \\
\hline County Zhambyl & 7.46 & 325.1 & 4.36 & 1.61 & 2.74 & 8.43 \\
\hline County Ayyrtau & 9.62 & 415.4 & 4.32 & 0.89 & 3.43 & 3.31 \\
\hline County Esil & 5.14 & 209.2 & 4.07 & 1.45 & 2.62 & 3.01 \\
\hline County Kyzylzhar & 6.15 & 245.0 & 3.98 & 3.45 & 0.54 & 3.46 \\
\hline County Mamlyutsky & 4.10 & 154.0 & 3.76 & 2.24 & 1.51 & 6.94 \\
\hline County Akkayyn & 4.71 & 155.9 & 3.31 & 1.10 & 2.21 & 8.20 \\
\hline County Timiryazevsky & 4.51 & 128.4 & 2.85 & 0.52 & 2.33 & 4.81 \\
\hline County M. Zhumabayeva & 7.81 & 166.6 & 2.13 & 0.98 & 1.15 & 2.69 \\
\hline County Ualikhanov & 12.88 & 230.3 & 1.79 & 0.57 & 1.22 & 8.77 \\
\hline City of Petropavl & 0.22 & - & - & - & - & 8.41 \\
\hline
\end{tabular}

As many as 9 out of 13 regions have a road density higher than the average for the whole country and 7 of them higher than the average for the region (Table 3). The length of roads in the counties of the region varies, depending on the development of infrastructure, settlement, and the presence of industrial, agricultural and other facilities in their area. The greatest length of roads is recorded in the area of G. Musrepova, it is $664.3 \mathrm{~km}$. The second place in terms of the length of roads is taken by the Taiynshinsky County $-613.2 \mathrm{~km}$. The third place belongs to the Ayyrtau County - 415.4 $\mathrm{km}$. The fourth and fifth places are shared by the Akzhar and Zhambyl Counties, with road lengths of $374.2 \mathrm{~km}$ and $325.1 \mathrm{~km}$ respectively. The shortest length of roads is in the Mamlyutsky region - $154 \mathrm{~km}$. Nevertheless, there are many well-known and significant ecological tourism sites in this area.

Among them is Minkeser Lake with healing mud, as well as the Mamlyutsky State Reserve (Baryshnikov et al., 2019). The collected data characterizing the length and density of the road network justify the conclusion that the road network is well developed in comparison to the entire country. It enables relatively (in the conditions of Kazakhstan) access to tourist attractions, the ability to reach some lakes, transit to other regions of the country and to the Russian Federation (Ismagulova et al., 2020). The density of the road network, above the national average (including G. Musrepov, Taiynshinsky, Akzhar, and Shal akyna regions), is related to numerous sediments established by the lakes (access to water and obtaining food).

At the same time, the quality of road surfaces does not always meet international standards, which is one of the possible problems for the development of the tourism industry in the region. However, in the years 2006-2019, the quality of roads clearly improved, increasing from 2.78 (2006) to 3.60 (2019), with the world average (for 141 countries) at the level of 4.07. Of all the regions in the north of Kazakhstan, the region of North Kazakhstan has the highest lakes $-4.62 \%$. Ualikhanovskiy county has the highest lake rate $-8.77 \%$. This ratio is slightly lower in the counties, Zhambyl $8.43 \%$ and Akkayyn $-8.20 \%$. Similarly, within the city of Petropavel, the lake rate is high, reaching $-8,41 \%$. Less than $5 \%$ of the lake surface is characterized by 8 regions, including the G. Musrepova County has the lowest lake surface index value (Figure 1). 
The analysis of the "average" lake surface indicators in the administrative division revealed their ranking. The maximum value of 1686.79 ha belongs to the Ualikhanov County. In addition, there was a sharp decrease in the indicator by half in the Akzhar region - 845.72 ha. Very low rates were recorded in the remaining 11 counties of the region, including less than 100 ha. Another index characterizing the share of lakes was determined, which indicates the share of the area occupied by lakes in the area of the area of the studied region. Thus, the Ualikhanovsky County has the highest lakes, which are 1.13 thousand $\mathrm{km}^{2}$. In the remaining 12 counties and the city limits of Petropavlovsk, the value of the indicator is lower than 1 (Figure 2).

The analysis of the number of lakes depending on the area allowed to draw some conclusions. The reservoirs ranging in size from 20 to 50 ha predominate. The smallest indicator concerns reservoirs up to 20 hectares. At the same time, as already mentioned, it should be noted that when compiling a database of lakes in the North Kazakhstan region, water bodies of less than 10 hectares were not taken into account (there are a lot of them, especially in the Zhambyl and Mamlyutsky counties). So the actual picture may be slightly different. The number of lakes from 50 to 100 ha and over 100 ha, 549 and 512, respectively, which is almost the same. One of the problems related to the development of the recreational

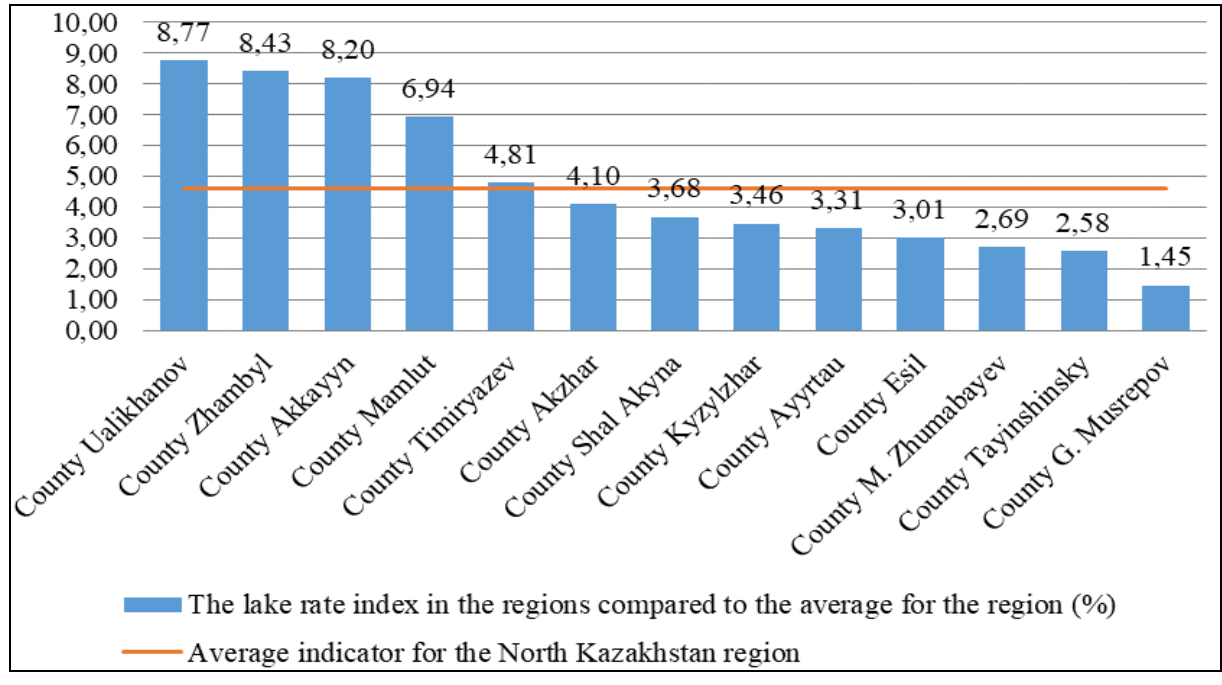

Figure 1. The lake rate index in the North Kazakhstan region, compared to the average for the study area (\%) (Source: based on the authors' calculations)

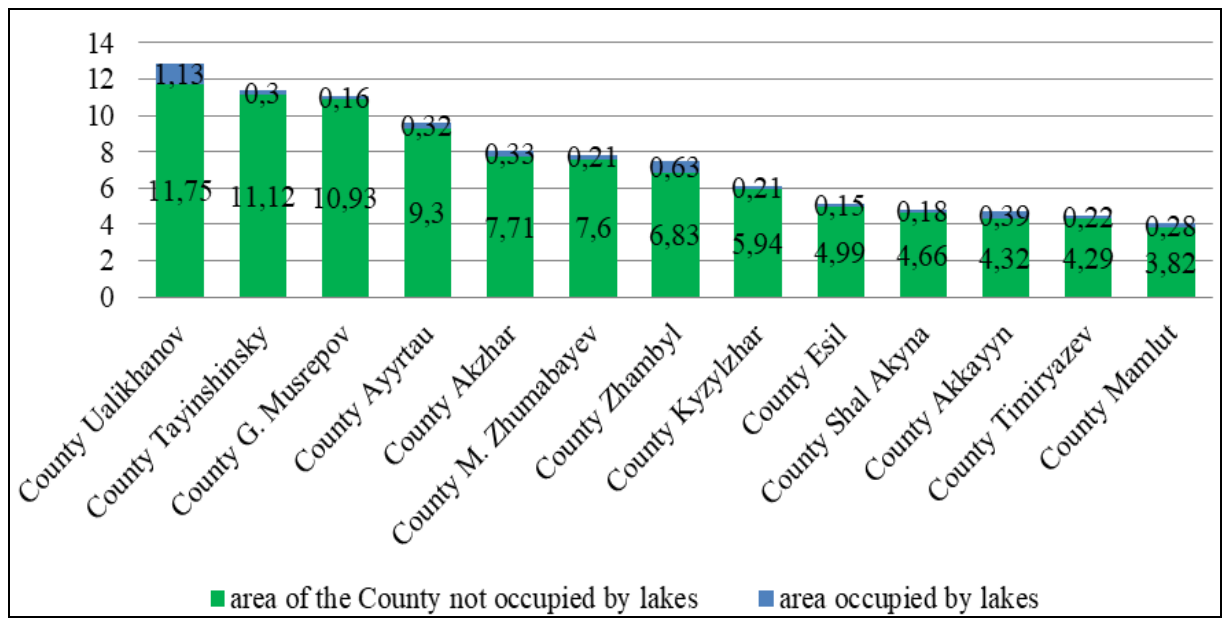

Figure 2. Ratio of the area of lakes in the counties to the area of the region of North Kazakhstan (thousand $\mathrm{km}^{2}$ ) (Source: based on the authors' calculations)

potential of lakes is their overgrowing. There is an increase in overgrowing of lakes with a smaller area, which can be seen in Figure 3. It can be assumed that the smaller the area of a lake, the more susceptible to degradation and eutrophication processes is. The anthropogenic factor is the main cause of lake degradation. Small-scale water bodies find it difficult to cope with anthropogenic pressures through natural processes, which inevitably leads to degradation. There are the largest water reservoirs

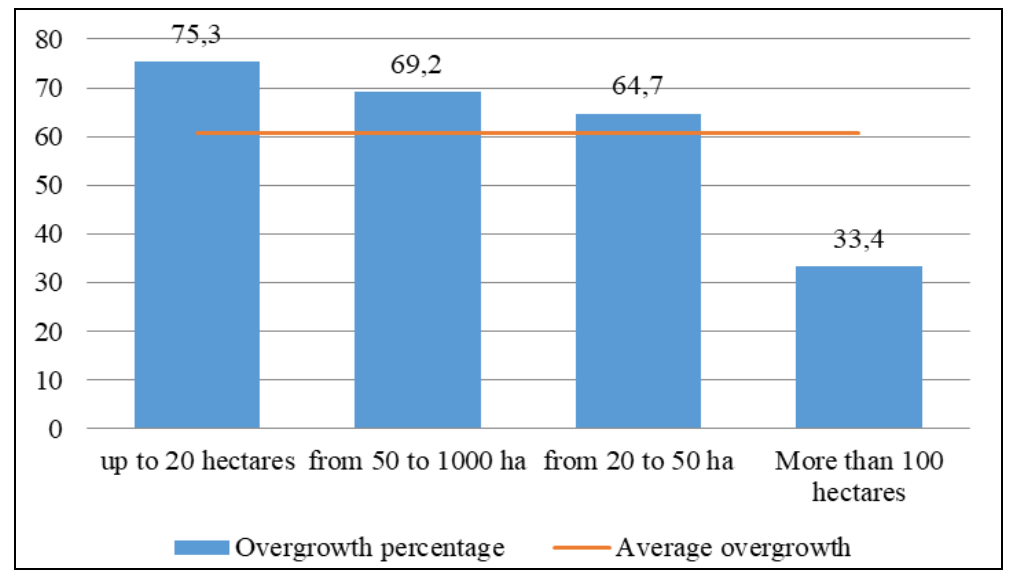

Figure 3. Dependence of lake overgrowth on their area (Source: based on the authors' calculations) in the study area. In the Aiyrtau - Imantau region, they cover $54.5 \mathrm{~km}^{2}$, Shalkar $-31.2 \mathrm{~km}^{2}$. In the Akzhar region, these are the lakes Ulken-Karoy 199.0 km2, Kishi-Karoy - 96.0 km². In Yesil Big Tarangul $-42.1 \mathrm{~km}^{2}$, in the Timiryazevsky area M. Kak - $39.6 \mathrm{~km}^{2}$. On the territory of the Mamlyut region, Minkeser Lake - $38.6 \mathrm{~km}^{2}$, Stanovoe $-29.6 \mathrm{~km}^{2}$. There are Seletyteniz lakes $-750.0 \mathrm{~km}^{2}$ in the Ualikhanov region, Teke $265.0 \mathrm{~km}^{2}$, and in the Tayynshinsky Kalibek region - $94.0 \mathrm{~km}^{2}$, Alabota - $27.4 \mathrm{~km}^{2}$ (Fomin, 2020). The largest water catchment area is the lake Seletyteniz $-750.0 \mathrm{~km}^{2}$. In favorable years, its depth reaches $3.2 \mathrm{~m}$, and the volume of water mass is $1.5 \mathrm{~km}^{3}$. It is supplied by the Sholaksay and Seleta rivers, as well as 19 streams. The average depth of the reservoirs in the region is 
1.5-2.5 meters, and the water volume depends both on the lake surface and the depth and season of the year. The amount of rainfall that determines the high flow of water bodies is very important. There are lake basins of various origins in the region: tectonic, hydrogenic, residual, suffusion-landslide, aeolian and thermocarp.

There are lake basins of various origins in the region: tectonic, hydrogenic, residual, suffusion-landslide, aeolian and thermocarp. The lakes are diverse in terms of their chemical composition and the degree of mineralization of the water. Reservoirs belonging to the classes of hydrocarbons and chlorides, rarely - sulphide ones, prevail. The mineralization ranges from 0.4 to $300 \mathrm{~g} / \mathrm{l}$ (self-deposited). Unleavened ones include those that have a salinity of up to $1 \mathrm{~g} / \mathrm{l}$. Water from such lakes is used for domestic needs and irrigation. Brackish tanks have a salinity of 1 to $25 \mathrm{~g} / \mathrm{l}$, water with a salinity of up to $2 \mathrm{~g} / \mathrm{l}$ can be used for drinking purposes, and up to $3.5 \mathrm{~g} / \mathrm{l}$ - for watering animals. At a concentration of $25-50 \mathrm{~g} / \mathrm{l}$ and higher, water is classified as salt. The water is bitter-salty in many of the region's lakes. Magnesium salts give it this flavor (Fomin et al., 2020).

The uniqueness of freshwater lakes determines their strategic importance as freshwater reservoirs. The share of fresh water in the lakes of the northern region of Kazakhstan is about $4 \mathrm{~km}^{3}$, in this respect almost all sediments in the region are located on the shores of fresh and brackish reservoirs. For example, the share of the three lakes Shagalalyteniz, Imantau, Saumalkol accounts for more than 900 million $\mathrm{m}^{3}$ of fresh water. The self-identification of the cultural and historical past of this territory is complemented by a variety of toponyms of hydronyms of Turkish and Russian origin. This creates an opportunity for the formation of ethno-ecological tourism (Moldakova and Dmitriyev, 2016; Tiberghien et al., 2017; 2018; Tiberghien, 2019) and ethno-cultural tourism (Bancerova and Kasimova, 2018; Tiberghien and Xie, 2018). As in other regions of the country (Saparov et al., 2017), the names most often reflect some important feature that distinguishes the reservoir that determines the quality of the water or its other characteristics: Bitter, Sól, Pitnoe, Zhamankol, Akkol, Karakol, Zhaltyrkol, Kyzylsor, Shirokoe, etc. Often the names of people such as Plekhanovo, Ponomarevo, Shitovo, Marushkino, etc. appear in the name of the lake. Many reservoirs are named after plants and animals - Kamyshnoye, Rogozyanka, Volchye, Sobachye, Kobylye, Tekekol, Koyandykol. Unfortunately, for most lakes it is impossible to determine the origin of their names.

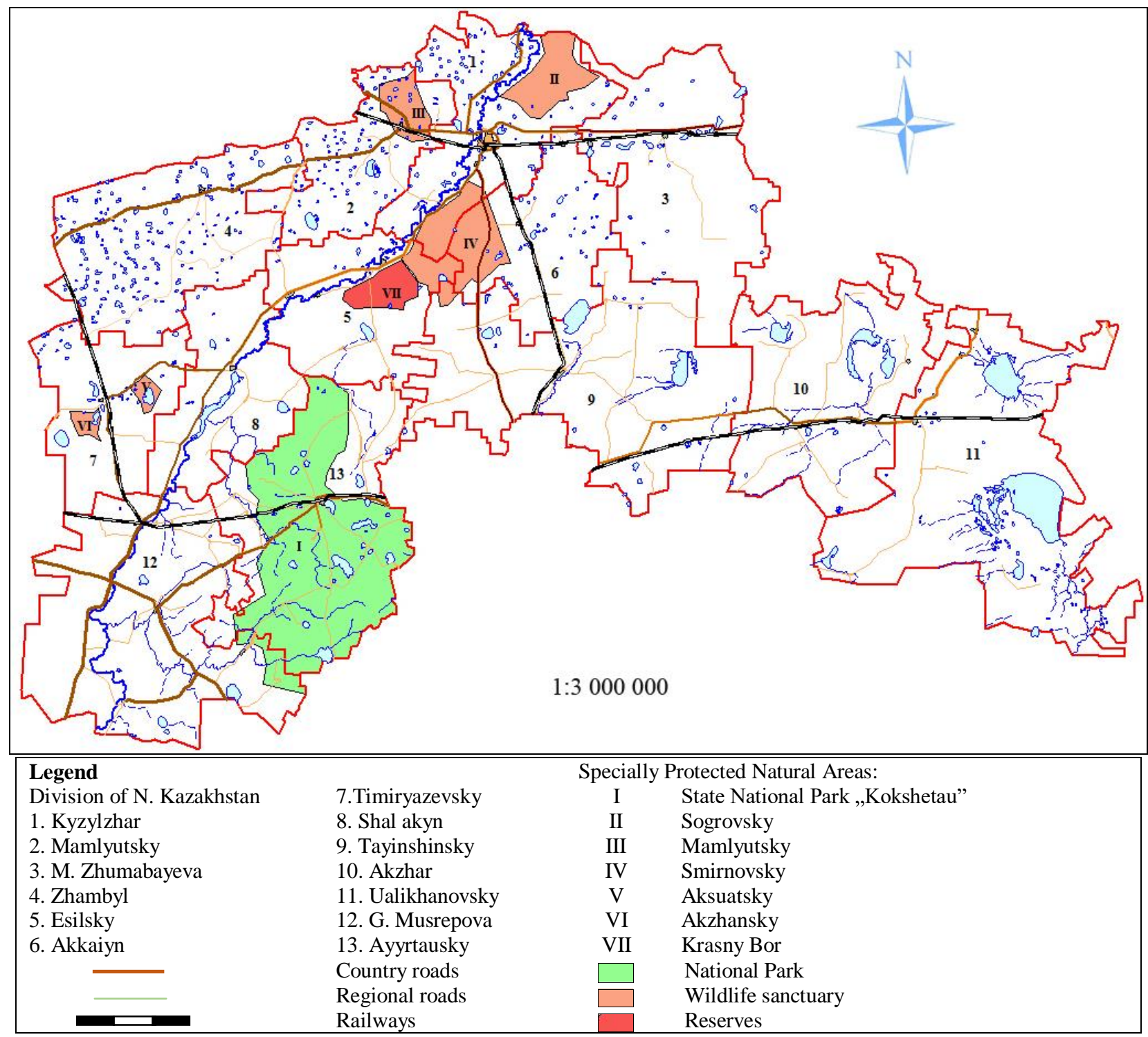

Figure 4. Distribution of reservoirs and nature areas under special protection, in connection with the transport routes of the North Kazakhstan region (Source: author development) 
The lakes are characterized by plant diversity, represented by vegetation immersed in water, and deposits of peat, reeds, etc. Peat deposits can be used as organic fertilizers, and reeds in construction can be used to produce house wall panels. There is practical experience and high positive results from using lakes submerged vegetation as food for domestic animals and birds.

The analysis of the results of mathematical statistics showed that in the region of northern Kazakhstan there is a large number of lake ecosystems, which are distinguished by their natural uniqueness, and have great recreational potential for the development of economic activities and tourism. The research results allowed for the creation of a schematic map visually confirming the natural and recreational potential of lake ecosystems, as well as reflecting the development of the transport network in the region (Figure 4). We assume that for the development of tourist and recreational potential large and deep water reservoirs used as recreational facilities, such as Bolshoi Tarangul from the Yesil region, Maly Tarangul from the Shal Akyna region, Shalkar and Imantau from the Aiyrtaussky region, etc., will be more in demand. At the same time, it is important to remember about shallow waters with a large layer of bottom sediments, represented by mineral silt, which enables their development as balneological objects. In many lakes, bottom sediments are represented by healing muds, which are widely used by the region's population, including Zhamankul (Zagradovka village), Minkeser (Minkeser village), Snezhinka Krivoye (Mirnoye village), Stanovoye (Stanovoye) village) of the region Mamlyut (Dmitriyev et al., 2018).

Each of the 13 administrative counties of the North Kazakhstan region has at least several unique lake systems that can be used to develop tourism. Since the population of the region makes extensive use of the recreational potential of local water reservoirs, one can speak of possible domestic tourism. The main factors of attractiveness are natural aesthetics, cultural and historical attractiveness, the presence of biological resources (mineral silt, fish, waterfowl).

The main addition is the features of the landscapes, with their unique charm. Based on the analysis of the annual limit of withdrawal of fish stocks in the region of northern Kazakhstan, the largest fish reserves are in Bolshoi and Maly Tarangul, Zhaksy Zhangistau, Kuspek, Kishi Karoy and Sergeevskoye lakes. The role of specially protected natural areas, which include unique natural landscapes, cultural and historical sites, is important. Sixteen prospective, specially protected natural objects have been scientifically confirmed in the region of northern Kazakhstan.

The reserves have been officially introduced, these are the Sogrovsky, Smirnovsky, Mamlyutsky reserves of national importance, as well as Akzhansky and Aksuatsky reserves of regional importance. The Sergeevskoe reservoir, built on the Esil River, as well as the river itself with numerous floodplain lakes, is of particular recreational importance for the region (Dmitriyev et al., 2020). Sergeevskoe reservoir is located in the Shal akyn area, it is about 100 kilometers long. This place is unique in terms of nature and recreation, it is recommended both for the beach and outside. There are unique landscapes and topography, rich flora and fauna, and a large number of floodplain lakes. There is a part of the "Kokshetau" State National Park in the Aiyrtau County. The ecosystems of the Shalkar and Imantau lakes are of particular importance for recreation. In their area, with unique landscapes, pedestrian and bus routes, ecological paths have been marked out, tourist service facilities were built, represented by holiday resorts, with a total capacity of about 500 people.

\section{CONCLUSION}

The raw material potential of northern Kazakhstan is certainly interesting. The high index of lakes in this area, the diversity of reservoirs and landscapes of the studied region indicate the possibility of using water ecosystems for economic purposes, for the development of ecological tourism and the tourism industry in general. The limited use of the natural potential of lakes today (mainly for fishing purposes) poses certain tasks for their future development as recreational and balneological facilities. Of course, lakes should be considered in conjunction with landscapes. This gives a wider range of recreational use, including horse riding, hiking, sunbathing and sightseeing, hunting for water game, fishing, picking berries, mushrooms, etc. The favorable geographical location of the North Kazakhstan region, the diversity of landscapes, the cultural and historical heritage, the location in the zone of the restricted region, the uniqueness of the nature of the forest-steppe region, are of interest to the development of tourism. It proves the enormous possibilities of domestic and international tourism development in the region. In the region of northern Kazakhstan, transport routes are well developed, compared to other regions of the country, which ensures traffic in its territory, including lake ecosystems. The motorways, especially in the Nur-Sultan - Petropavel direction, are of particular importance in this case.

Additionally, the border location of the North Kazakhstan region with the Russian Federation enables tourists from Russia to visit it (Batyrova et al., 2018). However, the analysis of road network density indicators, compared to other countries in the region, shows their relatively low value. Thus, higher values than the indicators for the rest of the country, the density of the road network does not ensure sufficient transport accessibility to areas with a high degree of lakes, which is a barrier to the development of tourism both domestic and the arrival of tourists from the Russian Federation.

At the same time, one of the main problems for the development of the recreational potential of the lakes of the North Kazakhstan region is the insufficient development of tourist infrastructure and services. Further research on recreational nature management is necessary for the harmonious and sustainable functioning of ecosystems, the development of scientific recommendations for the development of facilities in order to preserve their value.

\section{REFERENCES}

Abubakirova, A., Syzdykova, A., Kelesbayev, D., Dandayeva, B., \& Ermankulova, R., (2016). Place of Tourism in the Economy of Kazakhstan Republic. Procedia Economics and Finance, 39, 3-6. https://doi.org/10.1016/S2212-5671(16)30232-5

Aimagambetov, E., Bugubaeva, R., Bespayeva, R., \& Tashbaev, N. (2017). Model of sustainable development of tourism industry in Kazakhstan (regional perspective). Public Policy and Administration, 16(2), 179-197. https://doi.org/10.13165/VPA-17-16-2-02

Aliaskarov, D.T., Beisenova, A.S., Irkitbaev, S.N., Atasoy, E., \& Wiskulski, T. (2017). Modern changes in Zhezkazgan city: Positive and negative factors of tourism development (Kazakhstan). Geojournal of Tourism and Geosites, 20(2), 243-253. 
Aliyeva, S., Chen, X., Yang, D., Samarkhanov, K., Mazbayev, O., Sekenuly, A., Issanova, G., \& Kozhokulov, S. (2019). The Socioeconomic Impact of Tourism in East Kazakhstan Region: Assessment Approach. Sustainability, 11(17), 4805. http://dx.doi.org/10.3390/su11174805

Bancerova, O.L., \& Kasimova, A.R. (2018). Formation of ethnocultural tourism clusters in Russia-Kazakhstan borderline territory. Journal of Environmental Management and Tourism, 9(4), 771-776. https://doi.org.10.14505/jemt.v9.4(28).10

Baryshnikov, G., Fomin, I., \& Nasarova, T. (2019). Using mathematical modeling in predicting the economic efficiency of lake-commercial fish farming in cross-border areas of northern Kazakhstan. IOP Conference Series: Earth and Environmental Science, $395(1), 012017$. https://doi.org.10.1088/1755-1315/395/1/012017

Batyrova, N., Yermankulova, R., Mombekova, G., \& Jaxilikov, A. (2018). Economic problems of Kazakhstan's competitiveness in the international tourist business. Journal of Advanced Research in Law and Economics, 9(2), 396-408.

Bazarbekova, M., Assipova, Z., Molgazhdarov, A., \& Yessenov, M. (2018). Review of transportation modes in Kazakhstan region, Central Asia. Cogent Engineering, 5(1), 1450799. https://doi.org.10.1080/23311916.2018.1450799

Beletskaya, N.P. (1987). Geneticheskaya klassifikaciya ozernyh kotlovin Zapadno-Sibirskoj ravniny [Genetic classification of lake basins of the West Siberian Plain]. Geomorphology, 1, 50-58, (in Russian), Accessed 25.01.2021. https://cyberleninka.ru/article/n/geneticheskaya klassifikatsiya-ozernyh-kotlovin-severo-kazahstanskoy-ravniny

Bógdał-Brzezińska, A. (2020). Information and Communication Technology (ICT) as a source of development of states and regions in the age of globalization. Journal of Geography, Politics and Society, 10(1), 15-22. https://doi.org. 10.26881/jpgs.2020.1.03

Cerić, D., \& Więckowski, M. (2020). Establishing transboundary tourist space in the Baltic Sea region. Baltic Journal of Health and Physical Activity, 12(1), 149-157. http://doi.org/10.29359/BJHPA.12.Spec.Iss1.16

Chernova, E.O., \& Sukhova, M.G. (2017). Recreational-commercial zoning of Altai Mountains. Sustainable Development of Mountain Territories, 9(4), 362-368. https://doi.org.10.21177/1998-4502-2017-9-4-362-368

Chlachula, J. (2019). Geo-tourism perspectives in East Kazakhstan. Geography, Environment, Sustainability, 12(2), 29-43. https://doi.org.10.24057/2071-9388-2018-78

Chlachula, J. (2020). Geoheritage of East Kazakhstan. Geoheritage, 12(91). https://doi.org/10.1007/s12371-020-00514-y

Creswell, J. (2003). Research design: Qualitative, quantitative and mixed methods approaches (2nd ed). Thousand Oaks, CA: SAGE Publications.

Dinu, A.M. (2018). The importance of transportation to tourism development. Academic Journal of Economic Studies, 4(4), 183-187.

Dmitriyev, P.S., Fomin, I.A., \& Bekturganova M.B. (2013). K voprosu o sovremennom sostoyanii i znachenii ozer Severo-Kazahstanskoj oblasti [On the current state and significance of lakes of North Kazakhstan region]. Materialy mezhdunarodnoj nauchno-prakticheskoj konferencii «Kozybaevskie chteniya-2013: Kazahstan v mirovyh kul'turno-civilizacionnyh processah», NKSU named after M.Kozybaev, Petropavlovsk, 158-162, (in Kazakh), Accessed 28.01.2021. https://vossta.ru/k-voprosu-o-sovremennom-sostoyanii-i-znachenii-ozer-severo-kaz.html

Dmitriyev, P.S., Fomin, I.A., Teslenok, S.A., Nosonov, A.M., \& Lukashevich, A. (2020). Ekologicheskie obyekty Severo-Kazahstanskoj oblasti dlya formirovaniya bazy dannyh specializirovannoj GIS i sakral'nogo turistsko-ekskursionnogo marshruta [Environmental facilities of the North Kazakhstan region to form a database of specialized GIS and sacred tourist and excursion route]. Materialy konferencii. XI Vserossijskaya nauchno-prakticheskaya konferenciya. Geoinformacionnoe kartografirovanie v regionah Rossii, 2324.11.2020, VSU, Voronezh, 120-129, (in Russian), Accessed 25.01.2021.

Dmitriyev, P.S., Lysakova, T.N., Fomin, I.A., \& Glinskikh, V.V. (2016). Sovremennoe sostoyanie vodoemov Severo-Kazahstanskoj oblasti v usloviyah vliyaniya estestvennogo i antropogennogo faktorov [Current state of reservoirs of North Kazakhstan region under conditions of natural and anthropogenic factors]. Actual problems of humanities and natural sciences, Moscow, Russia, 2, 8-11, (in Russian), Accessed 25.01.2021. https://publikacia.net/archive/uploads/pages/2016_2_4/01.pdf

Dunets, A.N., Zhogova, I.G., \& Sycheva, I.N. (2019). Common characteristics in the organization of tourist space within mountainous regions: Altai Sayan region (Russia). GeoJournal of Tourism and Geosites, 24(1), 161-174. https://doi.org/10.30892/gtg.24113-350

Fomin, I., Nazarova, T., \& Baryshnikov, G. (2020). Ocenka urovnya rekreacionnogo potenciala ozernyh geosistem ravninnyh territorij Severnogo Kazahstana [Assessment of the level of recreational potential of the North Kazakhstan]. Problemy regional'noj ekologii, (1) (in Russian), Accessed 25.01.2021. https://doi.org.10.24411/1728-323X-2020-11088 https://www.elibrary.ru/item.asp?id=42978290

Fomin, I.A. (2020). Ozera Petropavlovskogo Priishim'ya respubliki Kazahstan: Ekologicheskaya ocenka, resursy, tendencii razvitiya [Lakes of the Petropavlovskoe Priishimye of the Republic of Kazakhstan: Environmental assessment, resources, development trends]. Doklad po rezul'tatam vypusknoj raboty. TyumSU, Tyumen, (in Russian), Accessed 25.01.2021.

Ismagulova, S.M., Dunets A.N., Dmitriyev, P.S., \& Janaleyeva, K.M. (2020). Tourist relation Kazakhstan with the countries of the commonwealth of independent states at the modern stage. GeoJournal of Tourism and Geosites, 31 (3), $1146-1152$. https://doi.org/10.30892/gtg.31328-551

Kalugin, O., Kurmangaliyeva, S., \& Tleuova, Z. (2019). Prospects for the use of the medical mud of Sora Arasan-Kunduzdy (south-east Kazakhstan) in balneology. Paper presented at the International Multidisciplinary Scientific GeoConference Surveying Geology and Mining Ecology Management, SGEM, 19 (1.2), 421-426. https://doi.org.10.5593/sgem2019/1.2/S02.054

Kantarci, K. (2007a). The image of Central Asia countries: Kyrgyzstan, Kazakhstan, Uzbekistan and Turkmenistan. Tourism Analysis, 12(4), 307-318. https://doi.org/10.3727/108354207782212468

Kantarci, K. (2007b). Perceptions of foreign investors on the tourism market in Central Asia including Kyrgyzstan, Kazakhstan, Uzbekistan, Turkmenistan. Tourism Management, 28(3), 820-829. https://doi.org/10.1016/j.tourman.2006.05.012

Kantarci, K. (2007c). Perceptions of Central Asia travel conditions: Kyrgyzstan, Kazakhstan, Uzbekistan and Turkmenistan. Journal of Hospitality and Leisure Marketing, 15(2), 55-71. https://doi.org/10.1300/J150v15n02_04

Korinth, B., Berdenov, Zh., Paskhvov, S.V., \& Wendt, J.A. (2019). The perception of vr of the tourists visiting chosen cultural facilities in Gdańsk. Ekonomiczne Problemy Turystyki, 1(45), 63-72. https://doi.org.10.18276/ept.2019.1.45-06

Kuralbayev, A., Myrzaliev, B., \& Sevim, B. (2016). Organizational and economic problems in the management of the spiritual - historical development of tourism in south Kazakhstan region. International Review of Management and Marketing, 6(2), 219-226.

Lewandowska, I. Drzewicki, A. \& Wendt, J.A. (2019). Awareness of the Cittaslow network among students in Olsztyn and Gdańsk cities. Polish Journal of Natural Sciences, 34(4), 559-573.

Michniak, D., Więckowski, M., Stępniak, M., \& Rosik, P. (2015). The impact of selected planned motorways and expressways on the potential accessibility of the Polish-Slovak borderland with respect to tourism development. Moravian Geographical Reports, 23(1), 1320. https://doi.org/10.1515/mgr-2015-0002

Moldakova, N.F., \& Dmitriyev P.S. (2016). Current state and prospects of development of ecological tourism of North Kazakhstan region. Journal The Way of Science, 10 (32), 84-86. 
Nazarova, T.V., Fomin, I.A., Dmitriev, P.S., Wendt, J.A., \& Janaleyeva, K.M. (2019). Landscape and limnological research of lake system of the plain areas of the northeastern borderlands of the Republic of Kazakhstan and assessment of their recreational capacity. GeoJournal of Tourism and Geosites, 25(2), 485-495. https://doi.org/10.30892/gtg.25217-375

Nazarova, T.V., Janaleyeva, G.M., Ilieş, D.C., Dmitriyev, P.S., Berdenov, Zh., \& Wendt, J.A. (2020). Research of water surface of lakes, plain territories of North Kazakhstan by using water indices, Vestnik KazNRTU, 137(1), 27-32. https://doi.org/10.51301/vest.su.2020.v137.i1.05

Page, S. (2004). Transport and Tourism. In Lew, A., Hall, C.M., Williams, A.M. (eds.), A Companion to Tourism, 146-158, Blackwell, Oxford.

Saparov, K.T., Yeginbayeva, A.Y., Nurgalieva, G.Z., Kulzhanova, S.M., Atasoy, E., \& Wendt, J.A. (2017). The question of Kazakh national and geographical toponymic as a potential factor of tourism development. Geojournal of Tourism and Geosites, 19(1), 115-125.

Semochkina, S.S. (2012). Ocenka landshaftno-rekreacionnogo potenciala ravninnoj territorii levogo berega Obi po biologicheskim pokazatelyam [Assessment of landscape and recreational potential of the flat territory of the left bank of the Ob by biological indicators]. Izvestia AltSU, 3/1 (75), 138-141, (in Russian), Accessed 25.01.2021. http://izvestia.asu.ru/2012/3-1/index.ru.html

Shakirova, S. (2015). Country images of Kazakhstan: From stereotypes and critique to positive national branding. Journal of Eastern European and Central Asian Research, 2(1). https://doi.org.10.15549/jeecar.v2i1.78

Smykova, M. (2015). The development of a tourist brand in Kazakhstan. Journal of Eastern European and Central Asian Research, 2(2). https://doi.org.10.15549/jeecar.v2i2.74

Syzdykbayeva, B., Raimbekov, Z., Khydyrbekuly, D., Temirbulatova, M., \& Bayandinova, A. (2015). Research note: Evaluation and projection of economic indicators of tourism development in Kazakhstan. Tourism Economics, 21(6), 1315-1322. https://doi.org/10.5367/te.2014.0406

Tiberghien, G. (2019). Managing the planning and development of authentic eco-cultural tourism in Kazakhstan. Tourism Planning and Development, 16(5), 494-513. https://doi.org/10.1080/21568316.2018.1501733

Tiberghien, G., \& Xie, P.F. (2018). The life cycle of authenticity: Neo-nomadic tourism culture in Kazakhstan. Journal of Tourism and Cultural Change, 16(3), 234-247. https://doi.org/10.1080/14766825.2016.1258408

Tiberghien, G., Bremner, H., \& Milne, S. (2017). Performance and visitors' perception of authenticity in eco-cultural tourism. Tourism Geographies, 19(2), 287-300. https://doi.org/10.1080/14616688.2017.1285958

Tiberghien, G., Bremner, H., \& Milne, S. (2018). Authenticating eco-cultural tourism in Kazakhstan: A supply side perspective. Journal of Ecotourism, 17(3), 306-319. https://doi.org/10.1080/14724049.2018.1502507

Tleubayeva, A. (2018). Rural tourism as one of the priority factors for sustainable development of rural territories in Kazakhstan. Journal of Environmental Management and Tourism, 9(6), 1312-1326.

Tulbayeva, A., Abdikarimova, M., Ganitaev, M., Imangulova, T., \& Pestova, A. (2017). Optimization problems distribution of investments for the implementation strategy of domestic tourism in Kazakhstan. Espacios, 38(47).

Vodopyanova, S.G. (1985). Rasprostranenie, morfometriya i morfologiya ozernyh kotlovin yuzhnyh ravnin Zapadnoj Sibiri [Distribution, morphometry and morphology of lake basins of the Southern Plains of Western Siberia]. Dissertation abstract. Novosibirsk: Institute of Geology and Geophysics of the USSR Academy of Sciences, 4-11, (in Russian), Accessed 27.01.2021. http://webirbis.spsl.nsc.ru

Watkins, M., Ziyadin, S., Imatayeva, A., Kurmangalieva, A., \& Blembayeva, A. (2018). Digital tourism as a key factor in the development of the economy. Economic Annals-XXI, 169(1-2), 40-45. https://doi.org/10.21003/ea.V169-08

Wendt, J.A. \& Bógdał-Brzezińska, A. (2018). Problematyka, metody i problemy badań w geografii turystycznej. In Olszewski-Strzyżowski D.J., Dróżdż R., Pasek M., (red.), Turystyka. Nowe Trendy, Zeszyty Naukowe, 7, Polska Izba Turystyki, 7-42.

Wendt, J.A. (2016). Tourism development challenges on the Dead Sea shore, Limnological Review, 2, 105-112. https://doi.org/10.1515/ limre-2016-0011

Wendt, J.A. (2020). Directions and area of tourism research in Kazakhstan. GeoJournal of Tourism and Geosites, 32(4), 1418-1424. https://doi.org/10.30892/gtg.32433-589

Werner, C. (2003). The new silk road: Mediators and tourism development in Central Asia. Ethnology, 42(2), 141-159.

Więckowski, M., Michniak, D., Bednarek-Szczepańska, M., Chrenka, B., Ira, V., Komornicki, T., Rosik P., Stępniak M., Székely V., Śleszyński P., Świątek D., \& Wiśniewski R. (2014). Road accessibility to tourist destinations of the Polish-Slovak borderland: 20102030 prediction and planning. Geographia Polonica, 87(1), 5-26. https://doi.org/GPol.2014.1

Więckowski, M., \& Saarinen, J. (2019). Tourism transitions, changes and the creation of new spaces in Central Eastern Europe. Geographia Polonica, 92(4), 369-377. https://doi.org/10.7163/GPol.0154a

Zhakupov, A.A., Saparov, K.T., Mazbaev, O.B., Dzhanaleeva, G.M., Musabaeva, M.N., Eginbaeva, A., \& Atasoy, E. (2015). Fundamentals of recreation-geographic assessment for tourism development. Oxidation Communications, 38(3), 1539-1544.

Zhidkoblinova, O. (2013). State policy of tourism industry development in the republic of Kazakhstan. World Applied Sciences Journal, 23(8), 1079-1084. https://doi.org.10.5829/idosi.wasj.2013.23.08.13128

Ziyadin, S., \& Takhtaeva, R. (2014). Trends and problems in tourism development on the territory of eastern Kazakhstan region. Actual Problems of Economics, 159(9), 232-236.

Ziyadin, S., Koryagina, E., Grigoryan, T., Tovma, N., \& Ismail, G.Z. (2019a). Specificity of using information technologies in the digital transformation of event tourism. International Journal of Civil Engineering and Technology, 10(1), 998-1010.

Ziyadin, S., Litvishko, O., Dubrova, M., Smagulova, G., \& Suyunchaliyeva, M. (2019b). Diversification tourism in the conditions of the digitalization. International Journal of Civil Engineering and Technology, 10(2), 1055-1070.

*** Kazakhstan: Roads quality (2021). Accessed 31.01.2021. https://www.theglobaleconomy.com/Kazakhstan/roads_quality/

*** Spravochnik po istorii administrativno-territorial'nogo deleniya Severo-Kazahstanskoj oblasti (2007) (29.07.1936-01.01.2007), [Handbook on the history of the administrative-territorial division of the North Kazakhstan region (29.07.1936-01.01.2007)]. Petropavlovsk, 361, (in Kazakh), Accessed 30.01.2021, Electronic resource: https://elib.skolib.kz/catalog/item386.html

*** World Fact Book, CIA (2020). Accessed 29.01.2021. https://www.cia.gov/the-world-factbook/field/roadways/ country-comparison/

Article history: Received: 12.02.2021 Revised: 26.02.2021 Accepted: 16.03.2021 Available online: 07.04.2021 